\title{
Determinants of defaulting by collateral lending groups in microfinancing: A probit regression approach
}

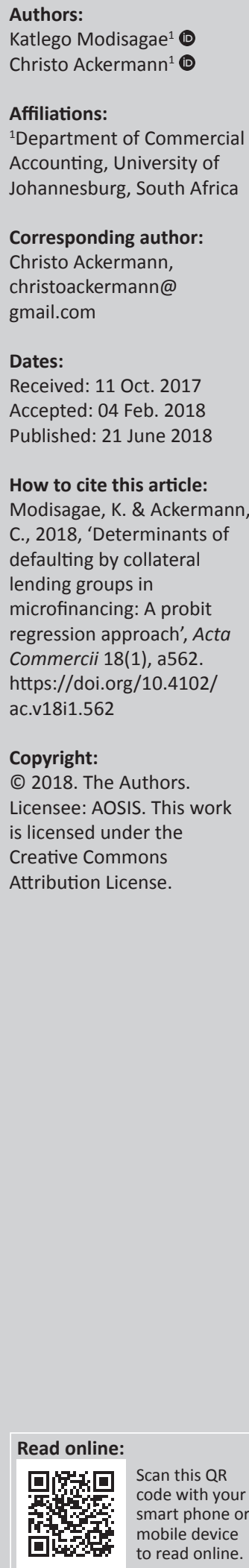

Orientation: Despite the use of group lending, microfinance institutions (MFIs) are still faced with the risk of default by borrowers and the absence of physical collateral means that there is no recourse to borrower assets for repayment. It is therefore imperative to understand characteristics of loan default as a means to reduce possible erosion of the capital base of MFIs.

Research purpose: The study identified determinants of loan default for collateral lending groups in microfinancing.

Motivation for the study: Default on loans, which can be caused by characteristics of the lending groups themselves, has the undesirable effect of eroding the capital base of MFIs and threatening their continued existence. This study aims to identify those characteristics of loan default which could erode the capital base of MFIs.

Research design, approach and methods: The study used the probit regression model to identify characteristics of loan default by collateral lending groups in microfinance in order to assist MFIs with insights regarding which factors to eliminate and which to enhance in the design of the groups to which they lend.

Main findings: The key findings of the study indicate that probability of default decreases with larger groups, more female borrowers in a group and larger borrower savings. The results also indicate that probability of default increases with larger loan amounts and with borrowers who have more business experience.

Practical and managerial implications: Microfinance institutions should consider having a feeder programme where borrowers whose businesses have become successful and larger can be passed on to bigger commercial banks instead of continuing to borrow from the MFIs as part of a group lending scheme.

\section{Introduction}

According to the World Bank's poverty headcount ratio indicator, $41 \%$ and $14.7 \%$ of people in sub-Saharan Africa and South Asia, respectively, live on under US\$1.90 a day (World Bank 2018). The situation in South Africa is also concerning; according to the latest available census data, the country's population is reported as 51.8 million citizens with a poverty headcount of $56.8 \%$ (Statistics South Africa 2012) and the country's unemployment rate as measured in the third quarter of 2017 is 27.7\% (Trading Economics 2018). Moreover, the 2014/2015 Living Conditions Survey carried out by Statistics South Africa indicates that 30.3 million citizens live below the official national poverty line (Statistics South Africa 2015).

There is a dichotomy in that microfinance has a mandate to lend to the poor. This money can be used by the borrowers to fund the individual micro-enterprises that they (borrowers) have created and to lift themselves out of poverty. On the other hand, microfinance institutions (MFIs) must manage the collection of these debts carefully if they want to remain in existence. Collateral lending groups (also referred to as joint liability groups) help MFIs to reduce credit risks that they are faced with. Collateral lending requires that the borrowers form a group with fellow borrowers where each borrower's loan is guaranteed by fellow group members and where no future loans can be granted to any group member unless all members in the group have paid their outstanding loans (Faridi 2011; Ghatak 1999; Stiglitz 1990). Group members are responsible for the screening, selection, monitoring, mutual support and payment enforcement of fellow group members. These activities performed by fellow group members invariably reduce the costs associated with the lending activity on the part of the lender (Bhatt \& Tang 2002). The use of collateral lending groups with joint liability is commonly referred to as the 'Grameen model' because of the pioneering 
efforts by the Grameen Bank of Bangladesh in designing group lending as a practice in the microfinance industry.

Through the use of joint liability, collateral lending groups reduce the credit risk faced by MFIs while at the same time creating an opportunity for rural poor persons to gain access to credit. Poor rural persons, who are the typical clients of MFIs, are often credit constrained because of their lack of physical collateral and the resulting high level of credit risk that this poses to the lender (Kugler \& Oppes 2005). The lack of collateral and the high credit risk render it impractical for conventional financial institutions like retail banks to extend credit to the rural poor (Ross \& Savanti 2005).

The purpose of this study is to identify, through a literature review, those characteristics of collateral lending groups that are largely associated with default behaviour and then to determine statistically, through the use of the probit regression model, which of the identified characteristics are predictors of loan default. Secondary MFI data in South Africa were used in order to understand which characteristics must be avoided by MFIs when designing lending groups. An understanding of the group factors that are highly associated with default behaviour will enable MFIs to avoid the prevalence of such factors among its joint liability groups and by so doing reduce the probability of default.

\section{Literature review}

Poverty remains one of the greatest challenges that the modern-day world is facing. Despite many developments and advances in the global economy, in technology and its capabilities to introduce efficiencies in economic activities, the global community has still not managed to reduce the poverty and suffering of the world's poorest to acceptably low levels.

The world's poor are still faced with the challenge of a lack of access to financial services. The International Finance Corporation (IFC)'s (2012) report on their microfinance operations in Africa mentions that over 3 billion people in developing countries do not have access to financial institutions and that only between $5 \%$ and $25 \%$ of households in sub-Saharan Africa have a formal relationship with a financial institution. The report further mentions that subSaharan Africa's MFIs constitute only about $2 \%$ of the world's MFIs. The IFC correctly notes in the same report that 'improved financial services are needed most in Africa's poorest economies and countries emerging from conflict'.

According to the Microfinance Information Exchange (commonly referred to as 'MIX') website (MIX 2011), there were 92.2 million microfinance borrowers across the world served by approximately 2000 MFIs reporting to MIX with a total gross loan portfolio of US $\$ 65.2$ billion. The sheer scale of demand for microfinance services is a glimpse of the important role that MFIs play in creating access to financial services for the poorest members of the global community. The issue of financial access in South Africa is also significant and is continuously receiving government attention. The importance of the issue of financial access in the country is captured in the following quote taken from an address made by Mr Pravin Gordhan (then Minister of Finance) at the Alliance for Financial Inclusion Global Policy Forum in Cape Town:

In South Africa, financial inclusion plays a vital role in the ongoing transformation and development of our society, and our desire to improve the lives of our people. In our efforts to boost economic growth, improve economic opportunities and promoting equality of opportunity, financial inclusion is of vital importance. The ability to use a transactional account to purchase goods and services, a savings account to preserve wealth, credit to increase productive capacity or improve the quality of life, and to use insurance services as a bulwark against unforeseen events and risks, can go a long way in facilitating a better life for the poor. (Gordhan 2012:3)

The formation of borrowing groups with joint liability and a threat of future denial of credit are intended to operate as 'social collateral' that serves as a substitute for physical collateral while at the same time helping to overcome the information asymmetry problem (Conning 2000 cited in Naveen \& Veerashekharappa 2011).

Clients are jointly liable for unpaid loans of fellow group members in the case of default and each group member is assumed to find it important to receive further loans to refinance his or her micro-enterprise. It is therefore in each member's best interest to select fellow group members who are considered good with making their loan repayments as and when they are due. Because the clients have detailed knowledge about their neighbours with whom they intend to form a borrowing group, it is a far easier exercise for them to assess the reliability of fellow group members in making loan repayments than it is for the MFI. The use of information residing with individuals in communities overcomes the information asymmetry problem (Ghatak 1999).

When clients make use of the information that they have about their community members to self-select fellow group members, a process of 'assortative matching' typically occurs. This is a process in which a good applicant will not want to be in a group with a bad applicant, as this will increase his or her cost of having to repay the loan of a fellow group member who has defaulted. This process culminates with 'good' applicants being paired with applicants of a similar risk profile and 'bad' applicants being paired with 'equally bad' applicants (Armendáriz 1999 cited in Kugler \& Oppes 2005). However, there remains the risk that, with the process of assortative matching, a group may be formed that consists only of risky (bad) clients. To mitigate the risk of this happening, MFIs also often require that each new group must be approved at loan centre level before loans can be disbursed.

During the group formation stage, a process of peer screening takes place when the clients use local information to assess potential fellow group members. Without the peer screening 
function and faced with the information asymmetry problem, the MFI would have to resort to adverse selection. This is a practice of charging universal high interest rates to compensate for the fact that the MFI cannot differentiate between low credit risk and high credit risk clients (Armendáriz \& Morduch 2010). Once the borrowing group is in existence, a process of peer monitoring and peer enforcement needs to continually take place in order to overcome various moral hazards. Peer enforcement recognises the fact that group members, because of their close social associations with one another, are able to institute several social sanctions against group members who are in default (Bond \& Rai 2002).

The combination of the above social factors (the screening of fellow borrowers, careful selection of fellow group members, the ability of group members to impose social sanctions on members in default and the fear of public humiliation of members not repaying) results in the 'social collateral' that serves as a collateral substitute for physical collateral (Bond \& Rai 2002).

Olomola (2000) categorises the factors that may lead to default into four groups: borrower-related causes, loan-userelated causes, lender-related causes and external factors. In addition to Olomola's four categories, there are other factors related to the design of the loan contract itself such as the loan amount and the repayment period of the loan (Roslan \& Karim 2009) as well as factors relating to the structural design of the borrowing group. A review of the literature on factors related to the design of the group reveals a number of group characteristics that have a varying effect on the probability of repayment.

Gender is one of the attributes that has extensively been studied by researchers. Females are found to be reliable repayers because their generally limited access to financing causes them to place greater reliance on future loans from the MFI (Armendáriz \& Morduch 2005 cited in D'Espallier, Guerin \& Mersland 2011). In addition, females are found to be generally mutually supportive of each other, to like working in groups more than males (Musona \& Coetzee 2001) and to be more reactive to pressure from loan officers to repay (D'Espallier et al. 2011). Studies have, however, been conducted where MFIs with a predominantly male client base have managed to achieve good repayment rates (Richman \& Fred 2010). This then challenges the prevalent notion that males are likely to default.

Observations made regarding the age factor are that younger borrowers generally conduct micro-enterprises as a shortterm activity while waiting for better employment prospects. Younger borrowers are more mobile, migrating from rural settings to urban areas for better jobs and a better social life (Oke, Adeyemo \& Agbonlahor 2007). Mobility is also related to the level of education. Higher levels of education also increase employment prospects and the level of mobility of borrowers, resulting in higher dropout rates from the MFI and consequential default (Olomola 2000).
The attendance of loan centre meetings (where each group's repayment performance is announced) is an important feature of most MFI group lending contracts in that a client's fear of public humiliation is used to dissuade him or her from default. Thus, a client's attendance of meetings is important and associated with higher repayment rates (Olomola 2000). However, frequent meetings increase transaction costs for both the lender and the borrower and account for some of the dropouts. The time spent attending meetings can be used productively in the micro-enterprise (Fischer \& Ghatak 2010).

Borrowers with better levels of education make better business decisions, run better businesses and are thus better placed to repay (Bhatt \& Tang 2002). Borrowers with more business experience and prior business training by the MFI are better positioned to run better micro-enterprises, to be more successful in doing so and to consequently become better repayers (Roslan \& Karim 2009). Borrowers generating more business income are also better repayers (Gomez \& Santor 2003).

Borrowers with limited or no alternative sources of credit are more reliable in repayment as their lack of other financing sources makes them dependent on the MFI's loan (Kritikos \& Vigenina 2005). Borrowers with higher savings have a large resource base for emergency expenditure and are thus less likely to divert micro-enterprise funds for personal use in cases of disaster. Larger savings in a way also indirectly serve as collateral for the lender and can be used to settle the loan during hard times. As a result, larger savings are associated with higher levels of repayment (Olomola 2000; Ross \& Savanti 2005). However, the South African context is characterised by low levels of savings by households generally (Masilela n.d.) and some of the bad savers still remain reliable in meeting monthly repayment obligations for their varying levels of unsecured lending. The Quarter 3 2014 Consumer Credit Index Report issued by TransUnion (2014), a reputable local credit bureau, indicates that South African households are heavily indebted. Their estimated national household debt to financial institutions to disposable income is $73.5 \%$. In compiling their credit index, 56.5 million consumer accounts were measured and only 3.6 million accounts were 1 month or more in arrears.

Default is often associated with larger loan amounts, bigger repayment instalment amounts and later loan cycles (all members of the group should have repaid amounts lent to them before another round or cycle of loans is given to them) (Armendáriz \& Morduch 2010). Larger loan amounts tempt borrowers to invest in riskier ventures (Madajewicz 2004). Group dynamics in later loan cycles are different from initial loan cycles in that the levels of business success (and hence the riskiness) of group members may be different to such an extent that less successful members with lower loan amounts feel exploited when having to guarantee the larger loans of more successful members (Paxton 1996 cited in Kritikos \& Vigenina 2005). 
More frequent collection of repayment instalments is widely associated with better repayment rates (Fischer \& Ghatak 2010). The economic realities of microfinance customers are such that there is an ever-present temptation to use microenterprise profits towards day-to-day living expenses instead of making repayments. Frequent repayments instil some fiscal discipline and reduce the temptation faced (Yunus \& Jolis 2003 cited in Fischer \& Ghatak 2010).

According to Abbink, Irlenbusch and Renner (2006), bigger group sizes create room for increased free riding by group members who do not want to apply themselves in their microenterprises. In-group coordination can be better achieved in smaller groups (Ghatak \& Guinnane 1999 cited in Abbink et al. 2006) but larger groups have the advantage of having more voices to speak against a misbehaving member. Larger groups, however, can also find themselves in situations where each member neglects their monitoring and disciplinary duties under the presumption that these are performed by other group members. Despite all these factors, some large groups have been found to manage to maintain decent repayment rates (Guttman 2007).

Rural communities are typically more close-knit and better placed to impose social sanctions on defaulting members. Coupled with limited access to credit, rural borrowers are more likely to repay than urban borrowers (Kugler \& Oppes 2005). However, the South African context has urban townships with very close-knit communities placing them in a better position for reliable repayment.

Borrowers tend to become less stringent when performing the screening function on relatives; thus, having relatives in the same group is associated with higher levels of default (Sharma \& Zeller 1997 cited in Hermes, Lensink \& Mehrteab 2006). Micro-enterprises conducted as family-run businesses using MFI loans in some instances have the extensive involvement of other family members who are themselves not MFI clients. Some of these family-run businesses still, however, manage to achieve good repayment rates.

Diversification of business risk could be perceived as a superior option where group members have formalised insurance agreements where members will assist a member who experiences business losses and that member will repay them later. Ahlin (2007) concludes that borrowers prefer group members with similar business risk because if one borrower fails, fellow group members are also likely to fail and will thus not be held liable for repayment. In other words, 'groups anti-diversify in order to lower liability for their partners' (Ahlin 2007). The author rightfully notes that this homogeneous matching in terms of business risk in a group defeats the purpose of joint liability groups and places the lender in high risk should all businesses run by a group fail. This may prompt lenders to try to encourage business risk diversification while at the same time allowing the groups to self-select in order to have homogeneity in terms of borrower (individual) risk.

\section{Overall research approach}

Purposive sampling was used to select the MFI from which secondary data were obtained and used to test which lending group characteristics are predictors of loan default. The database of the Small Enterprise Foundation (SEF) was purposively selected to provide the sample data for this study. Small Enterprise Foundation is the largest MFI in South Africa that applies the Grameen group lending model and, with operations mainly in Limpopo, is located and targeted at some of the poorest citizens in the country. The entity has a long operational history and has been independently rated as socially committed, with good systems and adhering to social mission and values. These criteria are argued in making SEF information rich for the purpose of this research and the analysis from SEF could be informative to other MFIs. The data used in the study consist of secondary data collected from the databases maintained by SEF as part of their normal daily operations. Small Enterprise Foundation has a separate data set for its micro-credit programme (MCP); the programme is intended for poor persons who need microloans to support their already existing micro-enterprise ventures.

Various data points are given about each loan: customer number, group number, group name, group size, age of the borrower, the gender of the borrower, the cycle of the loan, loan amount, date of loan disbursement, loan duration, instalment size, the years in business of the borrower, business savings of the borrower, business assets (cash, inventory, debtors and equipment), the type of business, loan centre of the borrower, loan centre to which the group belongs, the region under which the group falls and the geographical area where the group is located. The characteristics associated with loan default are analysed by looking at default at collateral group level. Therefore, the unit of analysis for the study was a group rather than individual borrowers in the group.

The data provided in the MCP file were aggregated to group level, which for most variables entailed calculating the average for the variable concerned (e.g. average age of group members, average loan amount in the group). Where necessary, variables were converted into dummy variables (e.g. group where all members are female $=0$ and a mixedgender group $=1$; no groups had all members being male). The data files from SEF, however, do not contain data for all the characteristics that have been identified as potential contributors to default behaviour. Data analysis was thus only performed on the characteristics for which data are available for analysis.

These characteristics are:

- age of the borrower

- gender of the borrower

- size of the group

- loan amount

- loan cycle

- instalment size

- repayment frequency 
- loan duration

- years in business

- business savings

- business assets.

In this study, the relationship between collateral lending group characteristics and repayment behaviour is examined. This is thus an examination of relationships between variables where default is dependent on the various group characteristics identified through the literature review. The dependent variable is dichotomous because the predicted outcome is whether the group will default or not. This then means that the appropriate regression method to examine the relationship is the probit model. The probit regression model was then presented to determine those variables that impact significantly on the probability of loan default.

The probit model is expressed as

$Y=\beta_{0}+\beta_{i} X_{i}+\varepsilon_{i}$,

where $Y$ is the dichotomous dependent variable, which can be explained as $Y=1$, if group defaults, and $Y=0$, if group does not default.

$\beta_{0}=$ is the intercept.

$\beta_{i}$ are the regression coefficients that explain the probability of default by borrowers.

$\varepsilon_{i}$ is the error term.

$X_{i}=$ independent variables $(i=1,2,3 \ldots \ldots 11)$ as defined in Table 1.

The coefficients of the probit model results however do not directly show, as is the case with linear regression models, the magnitude of the change in probability that occurs for a one unit change in the independent variable. To measure magnitude, a marginal effects analysis was performed. Marginal effects indicate the percentage change in the probability of the dependent variable taking a certain outcome given a one unit change in the independent variable (Econometrics Academy 2013; Gujarati \& Porter 2009; Wooldridge 2002). The percentage change in probability

TABLE 1: Independent variables used in the probit model.

\begin{tabular}{ll}
\hline Variable number & Variable name \\
\hline$X_{1}$ & Group Size (average size of the group) \\
$X_{2}$ & GenderDummy (is the group all female or mixed) \\
$X_{3}$ & AGE (average age of group members in years) \\
$X_{4}$ & LOAN (average loan amount of the group) \\
$X_{5}$ & CYCLE (average loan cycle of the group) \\
$X_{6}$ & LoanDurationDummymonths (average loan repayment duration) \\
$X_{7}$ & RepaymentFrequecyDummy (average months gap between \\
$X_{8}$ & payments) \\
$X_{9}$ & InstalmentSize (average instalment size of the group) \\
$X_{10}$ & YearsinBusiness (average years in business of the group) \\
$X_{11}$ & BusinessSavings (average business savings in the group) \\
\hline
\end{tabular}

as calculated in marginal effects analysis is interpreted as is and thus there are no widely known parameters in research where a particular range of percentage changes is regarded significant. For the purposes of this study, any variable that creates a percentage change that is greater than $10 \%$ was regarded as having a significant effect on the probability of default.

To contribute to the overall validity and reliability, the results and the chosen probit regression model were peer-reviewed. Probit analysis is also regarded as a valid tool used to investigate matters directly relating to repayment or default (as applied in this article) (Perez 2012). After the data were executed in the regression model, SPSS was used to run the internal consistency score. The reliability was calculated at an acceptable level of 0.70 (Fourie \& Ackermann 2013; George \& Mallery 2003). This therefore indicates that the basket of items used to identify those collateral group characteristics that are highly associated with default behaviour is reliable.

\section{Results}

The aim of this section is to present a detailed analysis of the attributes of collateral lending groups that are likely to lead to default on microloans granted to clients.

The probit model

$Y=\beta_{0}+\beta_{1} X_{i}+\varepsilon_{i}$

was fitted to the data. All 11 independent variables for which data were collected were used in the model. The probit model was converged and Table 2 presents the results.

All variables included in the analysis have a $p$-value less than 0.01 except for loan duration. Loan duration is therefore found not to be a significant predictor of probability of default.

In order to interpret the probit model, the marginal effects were calculated. In this regard, a one unit change in the following variables decreases the probability of defaulting by the stated percentages: group size by $8.63 \%$, gender by $14.86 \%$, age by $1.32 \%$, cycle by $4.36 \%$, repayment frequency by $6.44 \%$, instalment size by $0.09 \%$, business savings by $0.10 \%$ and business assets by $0.00 \%$. On the other hand, a one unit

TABLE 2: Marginal effects of the probit model on the micro-credit programme.

\begin{tabular}{lcccc}
\hline Variable & $\mathrm{dy} / \mathrm{dx}$ & $\begin{array}{c}\text { Delta method } \\
\text { Standard error }\end{array}$ & $\begin{array}{c}\text { Regression } \\
\text { coefficient }\end{array}$ & $p$ \\
\hline Group size & $-0.086298^{*}$ & 0.020331 & -0.791039 & 0.000 \\
Gender & $-0.148613^{*}$ & 0.026653 & -0.086298 & 0.000 \\
Age & $-0.013230^{*}$ & 0.00139 & -0.148613 & 0.000 \\
Loan & $0.000371^{*}$ & 0.00005 & -0.013230 & 0.000 \\
Cycle & $-0.043635^{*}$ & 0.00460 & 0.000371 & 0.000 \\
Repayment frequency & $-0.064414^{*}$ & 0.01480 & -0.043635 & 0.000 \\
Loan duration & -0.007182 & 0.019119 & -0.064414 & 0.707 \\
Instalment size & $-0.000875^{*}$ & 0.000211 & -0.007182 & 0.000 \\
Years in business & $0.014326^{*}$ & 0.003002 & -0.000875 & 0.000 \\
Business savings & $-0.001026 *$ & 0.000064 & 0.014326 & 0.000 \\
Business assets & $-0.000036^{*}$ & 0.000011 & -0.001026 & 0.001 \\
\hline
\end{tabular}

$*$, significance level at $p<0.01$. 
change in the following variables increases the probability of defaulting by the stated percentages: loan amount by $0.04 \%$ and years in business by $1.43 \%$. The variable loan duration did not significantly impact on the model because of a $p$-value that was more than 0.01 .

Based on the marginal effects, increasing group size by three more members decreases probability of default by $25.89 \%$ $(3 \times 8.63 \%)$. Adding three more females to a group decreases probability of default by $44.58 \%(3 \times 14.86 \%)$. Lending to borrowers who are 3 years older will result in a decrease of probability of default by $3.96 \%(3 \times 1.32 \%)$, while lending to borrowers who are three cycles more advanced will decrease the probability of default by $13.08 \%(3 \times 4.36 \%)$. Narrowing the repayment frequency by one extra month sets the decrease in probability of default at $6.44 \%$; because repayment frequency on the total sample is 1.6 months, it would not be practical to reduce it any further. Increasing the instalment size by R300.00 decreases the probability of default by $27 \%$ $(300 \times 0.09 \%)$. Increasing business savings by R300.00 decreases the probability of default by $30 \%(300 \times 0.10 \%)$.

Increasing loan amount by $\mathrm{R} 300.00$ will increase the probability of default by $12 \%(300 \times 0.04 \%)$, while increasing the years of business experience that borrowers have by 10 years will lead to the probability of default increasing by $14.3 \%(10 \times 1.43 \%)$. Therefore, repayment frequency and age are regarded as insignificant variables because of the percentage changes of $6.44 \%$ and $3.96 \%$, respectively.

\section{Discussion}

The results indicate that group size, gender, loan cycles, instalment size and business savings decrease the probability of default. The finding that larger group size leads to reduction in the probability of default could be linked to the fact that, as suggested by Stiglitz (1990), when a member who is part of a large group defaults, the individual contributions by the remaining members to cover the amount in default would be insignificant. In other words, larger groups have a better insurance effect than smaller groups. The finding that having more females in a group reduces the probability of default is also in line with the literature. Female borrowers have less access to credit facilities than men have and thus place greater reliance on ability to receive future credit (Bhatt \& Tang 2002). Female borrowers are found to be less aggressive in taking business risks, meaning that they will mostly invest borrowed funds in safer micro-enterprise ventures and consequently be able to meet repayment obligations (D'Espallier et al. 2011).

Literature indicated that default tends to occur in later loan cycles and larger instalment sizes; larger instalments and later cycles are usually associated with larger loan amounts because of the dynamic incentive of progressive lending (Armendáriz \& Morduch 2010). The findings in this study indicate that larger instalment sizes and later loan cycles decrease probability of default, while increase in loan amount leads to an increase in probability of default. This then appears to be a contradiction; there is, however, overwhelming support in the literature for larger loan amounts being associated with an increased probability of default. The literature reviewed indicates several possible reasons that may lead to default increasing with an increase in loan amount. Firstly, it is postulated that the borrower is likely to choose riskier business ventures when they have more capital at their disposal (Madajewicz 2004). Secondly, it is suggested that available optimal investment opportunities become progressively fewer with increased capital and thus the borrower may divert available funds to non-productive purposes (Guttman 2007). Thirdly, the effectiveness of the threat of future loan denial becomes weaker as loan amount granted to the borrower increases and naturally leads to increased probability of default (Guttman 2007).

The finding that probability of default decreases as loan cycles increase and instalment sizes increase is perhaps indicative of the fact that SEF's borrower base does not change their business ventures or choose riskier businesses as the loan capital available to them in later loan cycles increases. This means that they remain engaged in the same business ventures that had enabled them to make loan repayments in previous cycles. The finding that is also indicative of good policies by SEF is assessing customers for further loans as cycles increase. With regard to instalment sizes, there is also the possibility that borrowers do not necessarily reinvest all of the higher capital into their businesses. They may well opt to retain some of it in savings and rather repay higher instalments than the required minimum as and when they realise that they will not need all of the capital for their businesses.

The relationship of business savings with default is in line with the literature that was reviewed. Borrowers with larger savings have more funds to resort to in case of personal and family emergencies; borrowers with little or no savings are likely to use business funds in case of emergencies (Olomola 2000; Ross \& Savanti 2005). The findings that years in business increases the probability of default are contrary to what the literature suggests. Microfinance institution clients with more previous business experience are naturally expected to perform better in business and to have more capacity to repay their loans (Gomez \& Santor 2003).

\section{Conclusions and recommendations}

This study undertook to answer the following research question: which group characteristics are predictors of loan default for collateral lending groups? The objectives were to identify in existing literature those characteristics that may be potential contributors to default behaviour and to then perform probit regression testing on secondary data to determine which characteristics are predictors of loan default. The results of the probit model testing are that an increase in group size, gender, loan cycles, instalment size, business assets and business savings decreases the probability of default. Age, repayment frequency and business assets, however, have a small marginal change in the probability of 
default. An increase in loan amount and business experience increases the probability of default. Loan duration did not significantly impact the model.

Small Enterprise Foundation currently has a policy of having five members in a group and currently a great majority of borrowers are females. Regarding the gender composition of the groups, it is recommended that SEF must maintain its current policy position of having majority female borrowers. Regarding group size, the organisation is encouraged to endeavour to ensure that situations where group sizes fall below five are minimised. It is, of course, acknowledged that some of these situations are beyond the organisation's control (e.g. the inability of a group to find a replacement member soon after a member drops out, falls ill or passes away).

It is recommended that SEF must consider having a feeder programme with larger commercial banks where a borrower whose micro-enterprise has become successful and large can 'graduate' from being an MFI borrower to a commercial client. There is indeed a strong case for arguing that group lending is no longer an appropriate lending arrangement for such a borrower. Arrangements could even be put in place where SEF administers some aspects of the loan from the commercial bank to the client. This same recommendation equally applies to the finding that defaulters tended to have more business experience.

\section{Acknowledgements Competing interests}

The authors declare that they have no financial or personal relationships that may have inappropriately influenced them in writing this article.

\section{Authors' contributions}

K.M. was responsible for project execution, including initial fieldwork and writing up the results. C.A. was responsible for project lead and quality control and also reviewed for academic rigour and logical flow.

\section{References}

Abbink, K., Irlenbusch, B. \& Renner, E., 2006, 'Group size and social ties in microfinance institutions', Economic Inquiry 44(4), 614-628. https://doi.org/10.1093/ei/cbl001

Ahlin, C., 2007, How does micro-credit work? Risk-matching, diversification, and borrower selection: Preliminary draft, viewed 21 October 2013, from http:// sticerd.Ise.ac.uk/seminarpapers/dg09032009.pdf

Armendáriz, B. \& Morduch, J., 2010, The economics of microfinance, 2nd edn., The MIT Press, London.

Bhatt, N. \& Tang, S., 2002, 'Determinants of repayment in microcredit: Evidence from programs in the United States', International Journal of Urban and Regional Research 26(2), 360-376. https://doi.org/10.1111/1468-2427.00384

Bond, P. \& Rai, A., 2002, Collateral substitutes in microfinance, viewed 01 October 2011, from http://finance.wharton.upenn.edu/ pbond/research/limits-jul2-02.pdf

D'Espallier, B., Guerin, I. \& Mersland, R., 2011, Women and repayment in microfinance: Working paper 2009-2, viewed 21 October 2013, from https://liriastest.libis. Working paper 2009-2, viewed 21 October 2013, from https://
kuleuven.be/bitstream/123456789/388366/1/pdf_WP_200902.pdf

Econometrics Academy, 2013, Econometrics - Probit and logit models, viewed 21 July 2016, from https://sites.google.com/site/econometricsacademy/econometricsmodels/probit-and-logit-models

Faridi, R., 2011, 'Determinants of women's success in microcredit programs', Journal of Developing Areas 45, 167-189. https://doi.org/10.1353/jda.2011.0018

Fischer, G. \& Ghatak, M., 2010, Repayment frequency in microfinance contracts with present-biased borrowers, London School of Economics, London.
Fourie, H. \& Ackermann, C., 2013, 'The effect of COSO control environment attributes on the effectiveness of internal control: An internal auditor perspective', Southern African Journal of Accountability and Auditing Research 14(1), 31-44.

George, D. \& Mallery, P., 2003, SPSS for windows step by step: A simple guide and reference 11.0 update, 4th edn., Pearson, Boston, MA.

Ghatak, M., 1999, 'Group lending, local information and peer selection', Journa of Development Economics 60, 27-50. https://doi.org/10.1016/S0304-3878(99) 00035-8

Gomez, R. \& Santor, E., 2003, Do peer group members outperform individual borrowers? A test of peer group lending using Canadian micro-credit data, Bank of Canada Working Paper 2003-33, viewed 19 February 2018, from http://bibvir2. uqac.ca/archivage/17734833.pdf

Gordhan, P., 2012, Making financial inclusion real, Address at the Alliance for Financial Inclusion Global Policy Forum, Cape Town, South Africa, viewed 27 September 2013, from www.treasury.gov/comm_media/speeches/2012/2012092701.pdf

Gujarati, D.N. \& Porter, D.C., 2009, Basic econometrics, 5th edn., McGraw-Hill, Boston, MA.

Guttman, J.M., 2007, Repayment performance in microcredit programs: Theory and evidence, Working Paper, Networks Financial Institute: Indiana State University, viewed 29 October 2013, from http://ssrn.com/abstract=985890

Hermes, N., Lensink, R. \& Mehrteab, H.T., 2006, Does the group leader matter? The impact of monitoring activities and social ties of group leaders on the repayment performance of group-based lending in Eritrea, African Development Review: African Development Bank, Blackwell Publishing Limited, Oxford.

International Finance Corporation (IFC), 2012, Microfinance in Africa, International Finance Corporation, Johannesburg.

Kritikos, A.S. \& Vigenina, D., 2005, 'Key factors of joint liability loan contracts: An empirical analysis', Kyklos 58(2), 213-238. https://doi.org/10.1111/j.00235962.2005.00286.x

Kugler, M. \& Oppes, R., 2005, Collateral and risk sharing in group lending: Evidence from an urban microcredit program, Centro Ricerche Economiche Nord Sud, Università di Cagliari, viewed 19 February 2018, from https://www. microfinancegateway.org/library/collateral-and-risk-sharing-group-lendingevidence-urban-microcredit-program

Madajewicz, M., 2004, Joint liability versus individual liability in credit contracts, Columbia University Department of Economics discussion paper No.: 0304-18, Columbia University, New York.

Masilela, E., n.d., An overview of savings in South Africa, The South African Savings Institute, viewed 10 September 2014, from http://www.savingsinstitute.co.za

Microfinance Information Exchange (MIX), 2011, Mix market outreach, viewed 28 September 2011, from http://www.themix.org/mixmarket

Musona, D. \& Coetzee, G., 2001, Drop-outs among selected Zambian microfinance institutions: Causes and potential impact on product design, viewed 21 Octobe 2013, from www.spanish.microfinancegateway.org/files/20237_20237.pdf

Naveen, K.K. \& Veerashekharappa, A., 2011, Progressive lending as a dynamic incentive mechanism in microfinance group lending programmes: Empirical evidence from India, Working Paper Series 270, Institute for Social and Economic Change, Bangalore.

Oke, J.T.O., Adeyemo, R. \& Agbonlahor, M.U., 2007, 'An empirical analysis of microcredit repayment in southwestern Nigeria', Humanity and Social Sciences Journal 2(1), 63-74. https://doi.org/10.1300/10911350802081592

Olomola, A.S., 2000, Determinants of smallholder loan repayment performance: Evidence from the Nigerian micro-finance system, viewed 21 October 2013, from www.csae.ox.ac.uk/conferences/2000-oia/pdfpapers/olomola.pdf

Perez, J.A., 2012, 'Revisiting loan grant and default characteristics and women in microfinance', International Journal of Information Technology and Business Management 8(1), 46-54.

Richman, D. \& Fred, A., 2010, Gender composition, competition and sustainability of micro finance in Africa: Evidence from Ghana's microfinance industry, viewed 01 October 2011, from www.csae.ox.ac.uk/conferences/2011-EDiA/papers/175Dzene.pdf

Roslan, A.H. \& Karim, M.Z.A., 2009, 'Determinants of microcredit repayment in Malaysia', Humanity \& Social Sciences Journal 4(1), 45-52.

Ross, A. \& Savanti, P., 2005, Empirical analysis of the mechanisms of group lending Centre for Micro Finance Research, Institute for Financial Management and Research, viewed 19 February 2018, from https://www.microfinancegateway. org/sites/default/files/mfg-en-paper-empirical-analysis-of-the-mechanisms-ofgroup-lending-2005.pdf

Statistics South Africa, 2012, 2011 Census, viewed 20 January 2015, from http:// beta2.statssa.gov.za/

Statistics South Africa, 2015, Living conditions survey 2014/2015, Statistics South Africa, Pretoria.

Stiglitz, J.E., 1990, 'Peer monitoring and credit markets', The World Bank Economic Review 4(3), 351-366. https://doi.org/10.1093/wber/4.3.351

Trading Economics, 2018, SA unemployment rate, viewed 17 January 2018, from http://tradingeconomics.com/south-africa/unemployment-rate

TransUnion, 2014, TransUnion SA consumer credit index Q3 2014, viewed 20 January 2015, from http://www.transunion.co.za/za/docs/serviceSolutions/TUCCI_Q32014 report\%20Final.pdf

Wooldridge, J.M., 2002, Econometric analysis of cross section and panel data, Massachusetts Institute of Technology, Cambridge, MA.

World Bank, 2018, Poverty indicators, viewed 18 January 2018, from povertydata. worldbank.org/poverty/region 